\title{
The Enlightenment of Cool Japan Strategy to China's B\&R Initiative
}

\author{
Yu Yu' ${ }^{1}$, Yang Pingyu ${ }^{2}$ \\ ${ }^{1}$ Wenzhou Business College, School of Foreign Languages andinternational trade. \\ ${ }^{2}$ Wenzhou Business College, School of Management
}

Keywords: "Cool Japan", "B\&R", Culture.

\begin{abstract}
In 2013, General Secretary Xi Jinping proposed to build the "Silk Road Economic Zone" and the construction of "21st Century Maritime Silk Road", which is the "B\&R" strategic thinking of the core content. "B\&R" strategic thinking is a new model of international regional economic cooperation. Because of its many countries, different countries, different language, language complexity, cultural practices and religious diversity and other characteristics, decided to exchange and cooperation in the process there will be some difficulties, and "Cool Japan" strategy is Japan for overseas audiences to build a national image And brand strategy, its objective has gone beyond the pure "cultural industry strategy" category, for our country "B\&R" in cooperation with the countries along the process have some reference.
\end{abstract}

\section{Introduction}

With the "B\&R (The Belt and Road)" strategy to promote and implement, and achieved some excellent results, but by the current international factors such as the impact of complex political factors, some countries still have doubts, some misreading and even distorted yet Gradually eliminated. We should use various channels to objectively disseminate the cultural connotation of our "B\&R" cooperation initiative, disseminate, study and absorb the excellent culture of the country along the way of open and inclusive, adopt the cultural exchange and consolidate the foundation of public opinion, implement cross-border cultural management, promote "B\&R "Economic cooperation along the country, to achieve" a total of Lei "development. In this process will inevitably encounter some difficulties, "Cool Japan" strategy is Japan for overseas audiences to build a national image and brand strategy. Its essence is to enhance the cultural content of Japanese products, to create an annual value of the trillion yen brand value, establish the Japanese national brand and enhance the Japanese country's soft power. "Cool Japan" strategy in its implementation process at home and abroad in the excellent experience is worthy of our reference.

\section{2. "Cool Japan" strategy}

\subsection{Cool Japan}

"Cool Japan" strategy is the Japanese national level of cultural industry strategy, that is, the development of animation, games and other cultural and creative industries as a leader, combined with Japanese food, fashion and other cultural "new cultural industry" strategy. "Cool Japan" aims to change the "product output" as "cultural output", while promoting the development of Japan's economy at the same time to achieve the goal of expanding the impact of Japanese culture. "Cool Japan" strategy is the real connotation of the Japanese culture and the whole of Japan packaged packaging, marketing in the international market. "Cool Japan" strategy in the objective has gone beyond the pure "cultural industry strategy" category, the ultimate goal is to increase the country rich.

\section{2. "Cool Japan" origin}

"Cool Japan" was first proposed in 2002, "Cool Japan" first in the "foreign policy" academic 
journals by Douglas McGregor. In 2003, the United States, "Time magazine" agreed with Douglas's point of view, since "Cool Japan" began to pop. In May 2007, the Asian Gateway Strategic Conference presented the concept of "Japan's coolness". "Cool" concept put forward, caused widespread concern in Japanese society, and became synonymous with Japanese culture. June 8, 2010, the Japanese government set up a "Cool Japan room", June 18, "new growth strategy" to "Cool Japan" overseas business as a key growth area. May 2011, Japan clearly put forward to build "Cool Japan" development goals.

\subsection{The Connotation and Characteristics of "Cool Japan" Strategy}

"Cool Japan" strategy is the Japanese government to revitalize the continued downturn in the Japanese economy, enhance Japan's soft power an important measure. Overall, from the "Cool Japan" strategic connotation structure, mainly contains the following three key links: (a). The development of "Cool Japan" industry, to provide the creative soil to stimulate the Japanese. "Cool Japan" strategy clearly put forward the talent strategy, local strategy and business strategy three strategies. (b). "Cool Japan" strategy is mainly for the domestic, the core is shaping the brand. For the future "Cool Japan" industry development direction can be attributed to the following three areas with the combination. First, tap the regional vitality and enhance the international influence of the joint. (c). Enhancing overseas influence is the core of soft power and the key to the "Cool Japan" strategy. Set up "Cool Japan" overseas expansion platform. In order to promote Japanese culture, the Japanese government first in France, India, Singapore, China and other countries to carry out targeted and characteristic Japanese culture promotion activities. And according to the Japanese academic community comprehensive study of the world 22 countries and regions in the cultural industry market size and maturity, the Japanese culture of the acceptance and popularity of the situation, the spread of other related industries and the impact of the surrounding market, the four Aspects of the comprehensive indicators, the establishment of the "Cool Japan" strategy overseas focus, its weight shown in Figure 1.

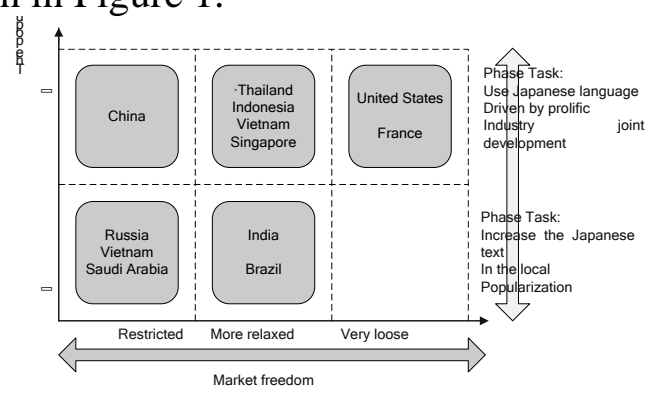

Figure 1. "Cool Japan" strategy overseas country inspection indicators

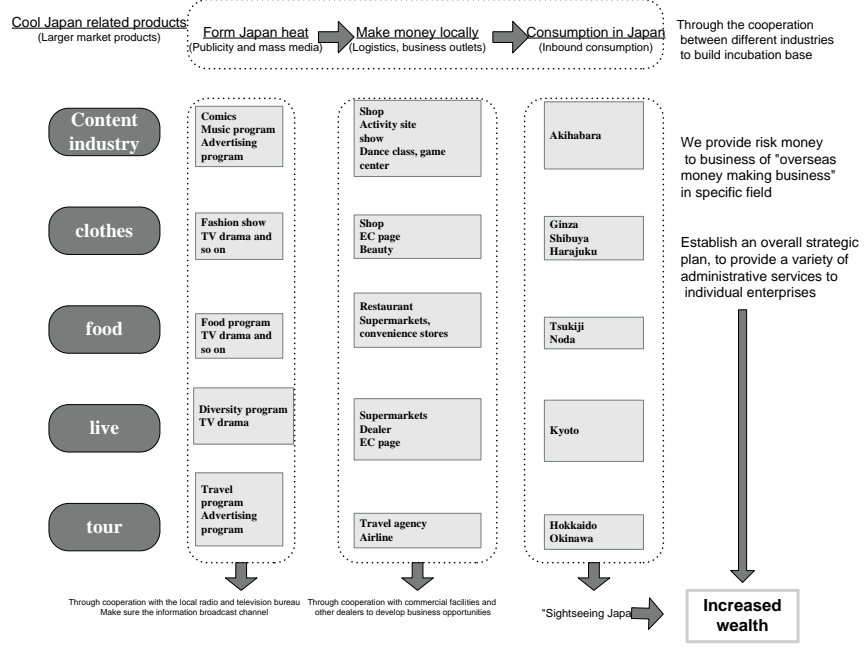

Figure 2. Cool Japan strategy internal structure 


\section{3. "B\&R" strategy}

\subsection{The origin of the "B\&R" strategy}

President Xi Jinping proposed to build the "Silk Road Economic Zone" initiative on September 7, 2013, when he visited the Central Asian countries Kazakhstan. When he visited the Southeast Asian countries in Indonesia on October 3, 2013, he proposed to build the "Silk Road of the 21st Century" ("Silk Road Economic Zone" and "21st Century Maritime Silk Road" referred to as "B\&R"), received the international community a high degree of concern. March 27, 2015 At the Boao Forum in Hainan, China's National Development and Reform Commission, the Ministry of Foreign Affairs and the Ministry of Commerce jointly issued the "Vision and Action to Promote the Economic Development of the Silk Road and the 21st Century Maritime Silk Road" (below Referred to as "vision and action"). This marks the development of China will have a historic impact on the "B\&R" strategy to enter a comprehensive stage of construction. The "B\&R" initiative initially involved 64 countries, with an additional four countries, as shown in Table 1.

Table 1. "B\&R" along the national scope

\begin{tabular}{|c|c|}
\hline Plate & Major country \\
\hline Central Asia & Kazakhstan, Kyrgyzstan, Tajikistan, Uzbekistan and Turkmenistan \\
\hline Mongolian & Mongolia, Russia \\
\hline $\begin{array}{l}11 \text { countries } \\
\text { in Southeast } \\
\text { Asia }\end{array}$ & $\begin{array}{c}\text { Vietnam, Laos, Cambodia, Thailand, Malaysia, Singapore, Indonesia, Brunei, } \\
\text { Philippines, Myanmar, Timor-Leste }\end{array}$ \\
\hline $\begin{array}{c}\text { South Asia } 8 \\
\text { countries }\end{array}$ & India, Pakistan, Bangladesh, Afghanistan, Nepal, Bhutan, Sri Lanka, Maldives \\
\hline $\begin{array}{l}\text { Central and } \\
\text { Eastern } \\
\text { Europe } 19 \\
\text { countries }\end{array}$ & $\begin{array}{l}\text { Poland, Czech Republic, Slovakia, Hungary, Slovenia, Croatia, Romania, } \\
\text { Bulgaria, Serbia, Montenegro, Macedonia, Bosnia and Herzegovina, Albania, } \\
\text { Estonia, Lithuania, Latvia, Ukraine, Belarus, Moldova }\end{array}$ \\
\hline $\begin{array}{l}\text { West Asia, the } \\
\text { Middle East } \\
19 \text { countries }\end{array}$ & $\begin{array}{c}\text { Turkey, Iran, Syria, Iraq, United Arab Emirates, Saudi Arabia, Qatar, Bahrain, } \\
\text { Kuwait, Lebanon, Oman, Yemen, Jordan, Israel, Palestine, Armenia, Georgia, } \\
\text { Azerbaijan, Egypt }\end{array}$ \\
\hline $\begin{array}{c}\text { four countries } \\
\text { (new) }\end{array}$ & New Zealand, South Korea, South Africa, Ethiopia \\
\hline
\end{tabular}

3.2. $\mathbf{R}$ "strategy and its significance

\subsubsection{B\& $\mathbf{R}$ "strategic connotation}

First, open. This is the basic spirit of the ancient Silk Road, but also "B\&R" the core concept of building. In other words, "B\&R" construction, the world of all countries or economies, international organizations, regional cooperation mechanisms and civil institutions open, in the institutional arrangements and mechanism design, do not engage in closed small circle, not exclusive.

Second, inclusive. This is a distinguishing feature from other cooperative organizations or mechanisms. On the one hand, it means that the "B\&R" parties are diversified, and all countries or regions that are willing to participate can become participants, builders and beneficiaries; on the other hand, it means that the diversity of forms of cooperation is not strictly harmonized The rules of participation. With the advantages of being inclusive, not only will not take the initiative to challenge the existing regional cooperation mechanism, but with the existing mechanisms to achieve a good docking.

Third, mutual benefit. This is to promote the "B\&R" building the fundamental driving force. Promote the "B\&R" construction, including China, including the participants, complement each other, to achieve benefit sharing, common development, not engage in zero and game, do not engage in interest to seize, colonial expansion, not the name of open, free trade Under the guise of engaging in beggar-thy-neighbor mercantilism, product dumping.

Fourth, the total camp. This is the basis for ensuring the sustainable development of "B\&R". "B\&R" is essentially a benefit to the co-sponsors to build a shared project. Only the parties to 
discuss, participate in, build together and benefit together to make it a "community of interests", "development community", and even "fate of the community."

\subsubsection{To build "B\&R" the great significance}

Promote the construction of "B\&R" will promote China to build a new comprehensive pattern. To build "B\&R" will provide a new impetus for the Chinese economy and the world economy. The establishment of "B\&R" will make an important contribution to the promotion of regional development and human peace in Asia and Africa. Building "B\&R" is conducive to optimizing and innovating international cooperation and global governance mechanisms.

\section{The Impact of "Cool Japan" on "B\&R"}

"Cool Japan" is one of the strategic features of the second session of the cabinet after the establishment of the first time in the cabinet set up a "Cool Japan" strategy to assume the minister, Cool Japan strategy to lead the Minister led the "Cool Japan promotion meeting" is "Cool Japan "strategy of the central leadership. Although the protagonist of the B\&R initiative is a business, the implementation of the strategy of Chinese enterprises going out is difficult to rely on the power of the firm itself, and it needs to be supported by the government at the institutional level. As in the institutional arrangements, it is necessary to create favorable environmental conditions, Economic policy, taxation and other aspects of the development of appropriate policies to promote the existing policy and measures to adjust and revise the times for enterprises to create a favorable international environment, establish or improve the "B\&R" along the country's agreements and accelerate the implementation.

Although China's cultural industry has made great progress in recent years, but the proportion of GDP is still far behind the Western developed countries, not only that, China's cultural industry, low degree of intensive, cultural export capacity is weak, cultural development is Imbalance, and "Cool Japan" strategy for China's development of cultural industries to enhance external influence is undoubtedly an important revelation. In the Japanese cultural mechanism, the government plays a leading role, but it maintains the spirit of tolerance and cooperation for the development of all kinds of actors in the cultural undertakings. Therefore, in the process of "B\&R" strategy development, we should construct the Chinese characteristics from the strategic height under the premise of improving the correct understanding and financial support of the potential resources of our culture, further improve the civil culture development mechanism, enhance the civil organization and the civil society The Role of Soft Culture in the Whole Cultural Resources.

"Cool Japan" strategy and other strategic enterprises in Japan in the early stages of overseas development, will generally take the form of cooperation, these cooperation is often based on the "loss" after the "profit" on the basis of long-term strategy, which can not only resolve the risk , But also win the trust of each other to achieve win-win situation. China's launch of the "B\&R" strategy, and the "Cool Japan" strategy to promote the 12 countries in the same overseas there are eight, which will inevitably make China and Japan in the "B\&R" along the regional culture, trade and other aspects Competition is becoming increasingly fierce. In the development of "B\&R" strategy should learn from the process, and we should uphold the development, win-win situation, the concept of mutual benefit go out; please come in, "out" with long-term development. In terms of economic cooperation, some places in our country still need advanced technology, equipment and advanced management mode. In addition, the cultural and other aspects, but also to strengthen cooperation, Chinese culture, art in the go out at the same time, the culture of the relevant countries should also be introduced to China, as Kyrgyzstan culture, Ministry of Information and Tourism Minister Sultan Layev said The development of humanistic cooperation, it is difficult to achieve the progress of economic cooperation.

\section{Summary}

"Cool Japan" strategy reflects the characteristics of the development of super-cultural industries. Compared with Europe and the United States, South Korea, the formation of the Japanese cultural 
industry is relatively late, the Japanese learning advanced countries in the development of cultural industry on the basis of experience, give full play to their own advantages, based on soft power theory, "creativity" and "emotional Value creativity "as the core, effectively put forward the rich Japanese characteristics of the" Cool Japan "strategy. "Cool Japan" strategy for China's development of cultural industries to enhance external influence is undoubtedly an important revelation.

China to promote the "B\&R" construction, we should sincerely treat the countries along the line, do words and beliefs, the line will be fruit in the principle of mutual benefit and win along with the countries to cooperate, so that countries along the benefit of China's development. The implementation of inclusive development, adhere to the opportunity to share the country, a total of challenges, create prosperity. "B\&R" is not a cluster of construction, is a long process, it needs to learn from each other to understand each other's culture, customs, history and social system, to reach each other. We must respect the cultural traditions of other countries, at the same time, we have to rely on various channels to our excellent culture, historical traditions and our voice passed to other people, to achieve our soft power output.

\section{References}

[1] Cheng Guoqiang. Build "B\&R": connotation, meaning and think tank mission [J]. China Development Watch, 2015 (04): 8-11.

[2] Yu Zhen Chong. Analysis of the Japanese cultural soft power development [D]. Liaoning University, 2013.

[3] Shi Runzhou. Cultural industry development and tourism destination image construction - "Cool Japan" strategy and its implications for Hainan [J]. Journal of Sichuan Institute of Tourism, 2014 (04): 75-77. 